Gontar, N.N. \& Vladimirova, D.A. (2021). Features of the budget management sustainability of the Republic of Tatarstan in the context of the COVID-19 pandemic. Management as a science of complex development. Collection of Scientific Articles. European Scientific e-Journal, 6 (12), 33-44. Hlučín-Bobrovníky: "Anisiia Tomanek" OSVČ.

Гонтарь, Н.Н., ВАадимирова, А.А. (2021). Особенности устойчивости управления бюджетом Республики Татарстан в условиях пандемии COVID-19. Management as a science of complex development. Collection of Scientific Articles. European Scientific e-Journal, 6 (12), 33-44. Hlučín-Bobrovníky: "Anisiia Tomanek" OSVČ.

DOI: $10.47451 /$ jur2021-04-001

EOI: $10.11244 /$ jur2021-04-001

The paper is published in Crossref, Internet Archive, Google Scholar, Academic Resource Index ResearchBib, JGate, ISI, CiteFactor, ICI, eLibrary databases.

\author{
Nina N. Gontar \\ Associate Professor \\ Candidate of Sciences in Jurisprudence \\ Faculty of Training Specialists for the Judicial System \\ Russian State University of Justice \\ St Petersburg, Russia \\ E-mail: ninagontar@mail.ru \\ Daria A. Vladimirova \\ Master's degree student \\ Faculty of Training Specialists for the Judicial System \\ Russian State University of Justice \\ St Petersburg, Russia \\ E-mail: ninagontar@mail.ru
}

\title{
Features of the budget management sustainability of the Republic of Tatarstan in the context of the COVID-19 pandemic
}

\section{Abstract:}

The study of the problems of management and development of regional budget policy within the state is one of the most important in management and law. The Republic of Tatarstan is considered a specific subject of the Russian Federation in the economic and territorial aspect. At the present stage of development of the Russian Federation, the Republic of Tatarstan has become one of the leading regional centres of investment in the field of science and business, where economic zones and industrial complexes are intensively developing. The object of this study was the budget of the Republic of Tatarstan and its statistical data for the comparison of 2019 and 2020. The purpose of the study was to identify trends in the budget of the Republic of Tatarstan during the COVID-19 pandemic related to budget management. The study concluded that Tatarstan, being a leader in the development of the socio-economic sphere, became one of the leaders in the Russian Federation in the development and implementation of its budget in the period 2015-2020, and also showed no obvious statistical signs of decline. Therefore, the experience of the budget policy of Tatarstan can be used to create algorithms for budget management in a crisis period. 
Keywords:

Tatarstan, budget policy, budget management, COVID-19.

Нина Николаевна Гонтарь Аоцент, кандидат юридических наук Факультет подготовки специалистов Аля судебной системы Российский государственный университет правосудия Санкт-Петербург, Россия E-mail: ninagontar@mail.ru

Аарья Аћексеевна ВАадимирова Магистрант Факультет подготовки специалистов Аля судебной системы Российский государственный университет правосудия Санкт-Петербург, Россия E-mail: ninagontar@mail.ru

\section{Особенности устойчивости управления бюджетом Республики Татарстан в условиях пандемии COVID-19}

\section{Аннотачия:}

Изучение проблем управления и развития региональной бюджетной политикой в рамках государства является одной из важнейших в менеджменте и юриспруденции. Республика Татарстан считается особым субъектом Российской Федерации в экономическом и территориальном аспекте. На современном этапе развития Российской Федерации Республика Татарстан стала один из ведущих региональных центров инвестирования в области науки и бизнеса, там интенсивно развиваются экономические зоны и промышленные комплексы. Объектом данного исследования являлся бюджет Республики Татарстан и его статистические Аанные на сравнении 2019 и 2020 годов. Целью исследования было выявление тенденций изменения бюджета Республики Татарстан в период пандемии COVID-19, связанные с бюджетным управлением. В ходе исследования были сделаны выводы о том, что Татарстан, являясь мидером в развитии социальноэкономической сферы, стала одним из Аидеров в Российской Федерации по развитию и реализации своего бюджета в период 2015-2020 годов, а также не проявица явных статистических признаков упадка. Следовательно, опыт бюджетной политики Татарстана может быть использован Аля созАания аАгоритмов управления бюджетом в кризисный период.

Kлючевые слова:

Татарстан, бюджетная политики, управление бюджетом, COVID-19.

\section{Introduction}


The study of the problems of management and development of regional budget policy within the state is one of the most important in management and law. The Republic of Tatarstan is considered a specific subject of the Russian Federation in the economic and territorial aspect. At the present stage of development of the Russian Federation, the Republic of Tatarstan has become one of the leading regional centres of investment in the field of science and business, where economic zones and industrial complexes are intensively developing.

The object of this study was the budget of the Republic of Tatarstan and its statistical data for the comparison of 2019 and 2020.

The purpose of the study was to identify trends in the budget of the Republic of Tatarstan during the COVID-19 pandemic related to budget management.

Based on the purpose of the study, the following tasks were solved:

- give a general historical-economic and physical-geographical description of the territory of the Republic of Tatarstan;

- determine the planned characteristics of the economic development of the region for 2020;

- conduct a comparative analysis of the index of the economic region in 2019 and 2020;

- identify trends in the economic development of the region in 2020 in comparison with 2020;

- evaluate the management of the budget policy of the Republic of Tatarstan in 2020.

During the study, comparative, historical and analytical methods were applied, which contributed to obtaining the necessary analytical materials and evaluating them.

The legislative documents and statistical data of the Republic of Tatarstan, published on the Internet on the official websites of the Government of the Republic and other portals, were used to achieve the goal and solve the tasks set.

\section{Social and economic characteristics of the Republic of Tatarstan}

The Republic of Tatarstan is one of the most famous and developed regions of the Russian Federation. The region is located in the very centre of the Russian Federation, on the Eastern European Plain, where the Volga and Kama Rivers merge (Fig. 1). Tatarstan is a part of the Volga Federal District and covers 67,847 square kilometres, and the population is slightly more than 3,000,000 people (About the Republic of Tatarstan, 2021). 
Tatarstan is considered a specific subject of the Russian Federation, as it has its state symbols: the flag, coat of arms and anthem. Its governing bodies almost completely repeat the structure of the governing bodies of the Russian Federation. The region is headed by the President. The Constitution of the Republic of Tatarstan is the general law on its territory. Kazan, the capital of the Republic of Tatarstan. It is located on the left bank of the Volga at the confluence of the Kazanka River.

All of the above features are due to the rich history of Tatarstan. Back in 1920, the Republic of Tatarstan became part of the Soviet Union (USSR) and was called the Tatar Autonomous Soviet Socialist Republic. After the collapse of the USSR, in the Perestroika period and numerous social and economic reforms of the 1990s, the region gained independence in politics, economy and culture, international relations. It had its logic of historical development (History of Tatarstan, 2001).

In its desire to preserve its sovereignty and systematic development within the Russian Federation, the Republic of Tatarstan did not mistake since the republic is a leader in the development of social, economic, cultural and scientific spheres at present. Such leadership helps to support the cultural development of the Russian Federation's population, and also allows providing various organizations and public authorities with professional personnel.

In the structure of the gross regional product of Tatarstan, the share of industry is $48.1 \%$, agriculture $-5.6 \%$, construction $-8.1 \%$, transportation and storage $-4.8 \%$. The Tatarstan industrial profile is identified by the petrochemical complex, large machine-building enterprises that produce competitive products, electrical and radio equipment developed. Tatarstan is also a region of high-intensity agricultural production. Occupying $2.2 \%$ of Russia's farmland, it produces $4.2 \%$ of its gross agricultural output.

The special economic zone of the industrial and production type Alabuga is actively developing, where 57 residents are located, of which 33 enterprises are engaged in industrial and production activities to produce competitive products. The unique project of the new city and the special economic zone of the technical and innovative type Innopolis are at the stage of intensive development. 84 companies are residents of the Innopolis SEZ, and 13 partner companies operate. In the republic, there are five territories of advanced social and economic development (TOSER) in Naberezhnye Chelny, Nizhnekamsk, Chistopol, Zelenodolsk and Mendeleevsk, where 62 residents are registered, and 3 residents are at the registration stage.

The share of small and medium-sized businesses in the gross regional product of the Republic of Tatarstan is $25.6 \%$. Tatarstan is actively developing the 
infrastructure of a small and medium-sized business. There are 93 infrastructure facilities in the republic (76 industrial sites and 17 industrial parks), where more than 1.4 thousand residents operate. The technopolis Khimgrad, the industrial site of the KIP Master, Innovation and Production Technopark Idea Inc., and the IT Park are successfully functioning (Economy of the Republic of Tatarstan, 2021).

The main financial bodies of the Republic of Tatarstan are the Ministry of Finance, which is directly involved in the development of the republic budget, and the Accounting Chamber, which reports on the work done. The legal basis of the Tatarstan budget system is the Budget Code of the Russian Federation, as well as the Budget Code of the Republic of Tatarstan. The legal basis also includes the Law of the Republic of Tatarstan On the Budget adopted annually. It operates following Article 2 of the Budget Code of the Republic of Tatarstan from January 1 to December 31 of the financial year (Budget Code of the Republic of Tatarstan, 2021).

Thus, being a leader in the development of the social and economic sphere, the Republic of Tatarstan has become one of the leaders in the Russian Federation in the development and implementation of its budget in the period 2015-2020. That is why the analysis of budget management in such a successful region of the Russian Federation is indicative and important for understanding the adaptation processes in the state in the era of the global crisis.

\section{Analysis of budget management index of the Republic of Tatarstan in 2020}

It is also important to note that the regional budget is executed following the deadlines set for its execution, and its index are always as close as possible to the planned ones, and sometimes even exceed them. And this happens even in particularly difficult conditions. For example, this index is the year 2020, when the whole world was covered by the COVID-19 coronavirus pandemic. According to paragraph 1, paragraph 1, Article 1 of the Law of the Republic of Tatarstan On the Budget of the Republic of Tatarstan for 2020 and the planning period of 2021 and 2022 dated 30.11.2019, No. 92-ZTR, the projected total budget revenues of the Republic of Tatarstan should have amounted to 274,430 million rubles, and expenditures310,555 million rubles (Law of the Republic of Tatarstan "On the Budget of the Republic of Tatarstan for 2020 and for the Planning Period of 2021 and 2022”, 2020).

The sudden pandemic, as well as the complete lockdown, called into question the achievement of the planned targets. So at once the social, cultural, sports and scientific spheres, which have always been the main mass of all revenues and expenditures of the republic's budget, were blocked. However, the development of 
a distance learning system and public education helped to get out of the situation, which helped to maintain the budget items of Tatarstan at the desired level. For the stable functioning of these systems, a huge amount of work was done, which resulted in the practical achievement of the planned budget index. Thus, according to the Report on the implementation of the consolidated budget of the Republic of Tatarstan and the budget of the Republic of Tatarstan as of 01.12.2020, it amounted to 258,724 million rubles in the revenue part and $267,191.7$ million rubles in the expenditure part (Report on the implementation of the consolidated budget, 2020).

During 2020, there was a significant dip in retail trade performance compared to the corresponding monthly figures for 2019. Particularly low index was obtained in April, when the relative trade index fell to $72.4 \%$ of the April 2019 figure. The same trends were observed in the index of the turnover of public catering $(37.0 \%)$ and the volume of paid services (59.7\%) (Fig. 2) (Shagiakhmetov, 2021). However, thanks to the adaptive methods of changing the budget policy, these indexes were able to return to acceptable percentages by the end of 2020 compared to 2019:

- retail trade turnover - to $95.2 \%$,

- the volume of paid services - to $92.2 \%$,

- $\quad$ the turnover of public catering - to $84.4 \%$ (Fig. 2) (Shagiakhmetov, 2021).

There was also a significant decline in the global cooperation and trade relations of the republic compared to 2019. The index was particularly low in September 2020 - only 65.1\% compared to September 2019. By the end of 2020, it was possible to slightly correct the situation, increasing the index to $69.5 \%$ (Fig. 3) (Shagiakhmetov, 2021). However, these percentages show that the republic's cooperation and trade relations are still far from returning to the index of the preSoviet era.

The gross regional product (GRP) of the Republic of Tatarstan during the pandemic did not show a particular tendency to decline or fail although the main share of the region's budget is oil and gas production, which showed a sharp drop in world prices against the background of lower production. GRP index did not fall below $97.0 \%$ relative to the corresponding index in 2019 (Fig. 4) (Shagiakhmetov, 2021). This suggests that the regional budget policy was able to adapt to the negative global trends and reorient some of the revenue items in favour of levelling the items that have a critical component for the region. When analyzing GRP, it is necessary to take into account the structural shares of the leading sectors of the economy:

- $\quad$ mining - 639.5 billion rubles, i.e., $26.1 \%$,

- manufacturing industry - 419.2 billion rubles, i.e., $17.2 \%$, 
- $\quad$ wholesale and retail trade-262.5 billion rubles, i.e., 10.7\%,

- construction - 190.1 billion rubles, i.e., $7.8 \%$,

- $\quad$ agriculture - 159.3 billion rubles, i.e., 6.5\% (Fig. 5-6) (Shagiakhmetov, 2021).

Based on the statistical data, it can be seen that the share of the four main industries accounts for just over $68 \%$ of the GRP of the Republic of Tatarstan or $2 / 3$ of the total GRP. Consequently, the revenue part of the budget of the republic is sufficiently diversified, which allows the critical periods of the development of the state or the world economy to adapt the expenditure items to achieve a more systematic and rapid output of budget performance index to the ones of the precrisis reporting period.

Also, comparing the average index of the Russian Federation and 2019, there is a fairly effective social and economic development $-0.2 \%$ more than the all-Russian index. A significant lag was observed in the construction industry (-4.1\%) and retail trade $(-2.1 \%)$ compared to the average figures for the regions of the Russian Federation. The lag in industries can be considered insignificant, as it was within 1\%. On the contrary, in the agricultural sector, there was progress compared to 2019 by $4.0 \%$, and with index for Russia by $2.5 \%$.

Table 1. Comparison of the main index of social and economic development for 2020 as a percentage of 2019

\begin{tabular}{|l|r|r|r|}
\hline & \multicolumn{1}{|c|}{ Russia } & \multicolumn{1}{|c|}{ Tatarstan } & \multicolumn{1}{c|}{ Comparison } \\
\hline GDP / GRP & $96.9 \%$ & $97.1 \%$ & $+0.2 \%$ \\
\hline Industry & $97.1 \%$ & $96.4 \%$ & $-0.7 \%$ \\
\hline Agriculture & $101.5 \%$ & $104.0 \%$ & $+2.5 \%$ \\
\hline Building & $100.1 \%$ & $96.0 \%$ & $-4.1 \%$ \\
\hline Retail trade & $95.9 \%$ & $93.9 \%$ & $-2.1 \%$ \\
\hline
\end{tabular}

Thus, the budget policy of the Republic of Tatarstan was correctly adapted to the current crisis conditions and prevented a sharp drop in index by the end of 2020 compared to the 2019 index and the average index for the Russian Federation's regions.

\section{Discussion}

The budget policy of the Republic of Tatarstan showed a sufficiently high level in 2020, which is reflected in the overall GRP index. However, to study the features of managing the budget potential of the region within the state, it is necessary to research the following two important positions: 
1. Analysis of the ratio of index of the trend in the development of industry structures compared to the share index in regional and state significance.

2. Search for index (markers) of the effectiveness of the regional budget policy of the state, taking into account the trend index in the development of industry structures.

The solution of these issues will help to create a more competent analytical method of the response and behaviour of the budget department to crises of the state and world level in the future.

\section{Conclusion}

Statistical data compared to the previous similar periods show the clarity and coherence of the system functioning even in emergencies. The level of budget indexes indicates the region's stability and the high professionalism of the authorities' personnel.

The pandemic has become a test for the region, as the flow of tourists, which previously averaged 3.5 million people annually, has rapidly approached several thousand people. The activity of scientific centres was stopped, and the educational process was blocked. In the republic, from March to September 2020, major sports events were discontinued. But it is these areas that make up the main content of the regional budget. However, Tatarstan could cope, proving that it is possible to maintain stability even in the most extreme situations. At the same time, removing the question of whether the budget has a future after the pandemic.

However, the regional budget policy has not shown clear statistical signs of decline. Continuing the trend of 2020, there is no doubt that in 2021 when the COVID-19 pandemic recedes, the budget targets of 274,636.7 million rubles in revenue and 281,668.3 million rubles in expenditure will be met and even as the restrictions are lifted will be exceeded (Law of the Republic of Tatarstan "On the Budget of the Republic of Tatarstan for 2021 and for the Planning Period of 2022 and 2023", 2020). Therefore, the experience of the Tatarstan budget policy can be used to create algorithms for budget management in a crisis period.

\section{References:}

About the Republic of Tatarstan. Retrieved March 2, 2021, from https://tatturk.tatarstan.ru/aboutrt (in Russian)

Budget Code of the Republic of Tatarstan № 35-ZRT from May 29, 2004. Retrieved March 17, 2021, from https://base.garant.ru/8118575 (in Russian) 
Economy of the Republic of Tatarstan. Official Tatarstan. Retrieved March 9, 2021, from

https://tatarstan.ru/about/economy.htm\#: :text=B\%20структуре\% \%20вацов ого \%20регионального \%20продукта,также \%20развитое \%20электро\%20и\%20ралиоприборостроение (in Russian)

History of Tatarstan. Training manual. - Kazan: Sh. Marjani Institute of History of the Academy of Sciences of the Republic of Tatarstan, 2001. (in Russian)

Law of the Republic of Tatarstan "On the Budget of the Republic of Tatarstan for 2020 and for the Planning Period of 2021 and 2022" № 92-ZRT from November 30, 2019. Retrieved March 14, 2021, from http://docs.cntd.ru/document/561621312- (in Russian)

Law of the Republic of Tatarstan "On the Budget of the Republic of Tatarstan for 2021 and for the Planning Period of 2022 and 2023” № 78-ZRT from November 27, 2020. Retrieved March 6, 2021, from http://docs.cntd.ru/document/571002953 (in Russian)

Report on the implementation of the consolidated budget of the Republic of Tatarstan and the budget of the Republic of Tatarstan from December 1, 2020. Retrieved March 16, 2021, from https://minfin.tatarstan.ru/2020-god.htm (in Russian)

Shagiakhmetov, M.R. (2021). Results for 2020. Tasks for 2021. Factors of ensuring economic development. Report at the extended meeting of the Board of the Ministry of Economy of the Republic of Tatarstan. - Kazan. (in Russian)

Pelevin, O.V. (2020). The main indicators of the forecast of social and economic development of the Republic of Tatarstan for 2021-2023. Report at the State Council of the Republic of Tatarstan. Kazan.

The main priorities of the formation of the budget of the Republic of Tatarstan (2018, April 20). Retrieved January 10, 2021, from https://kazedu.com/referat/166099/6 (in Russian) 


\section{Appendix}

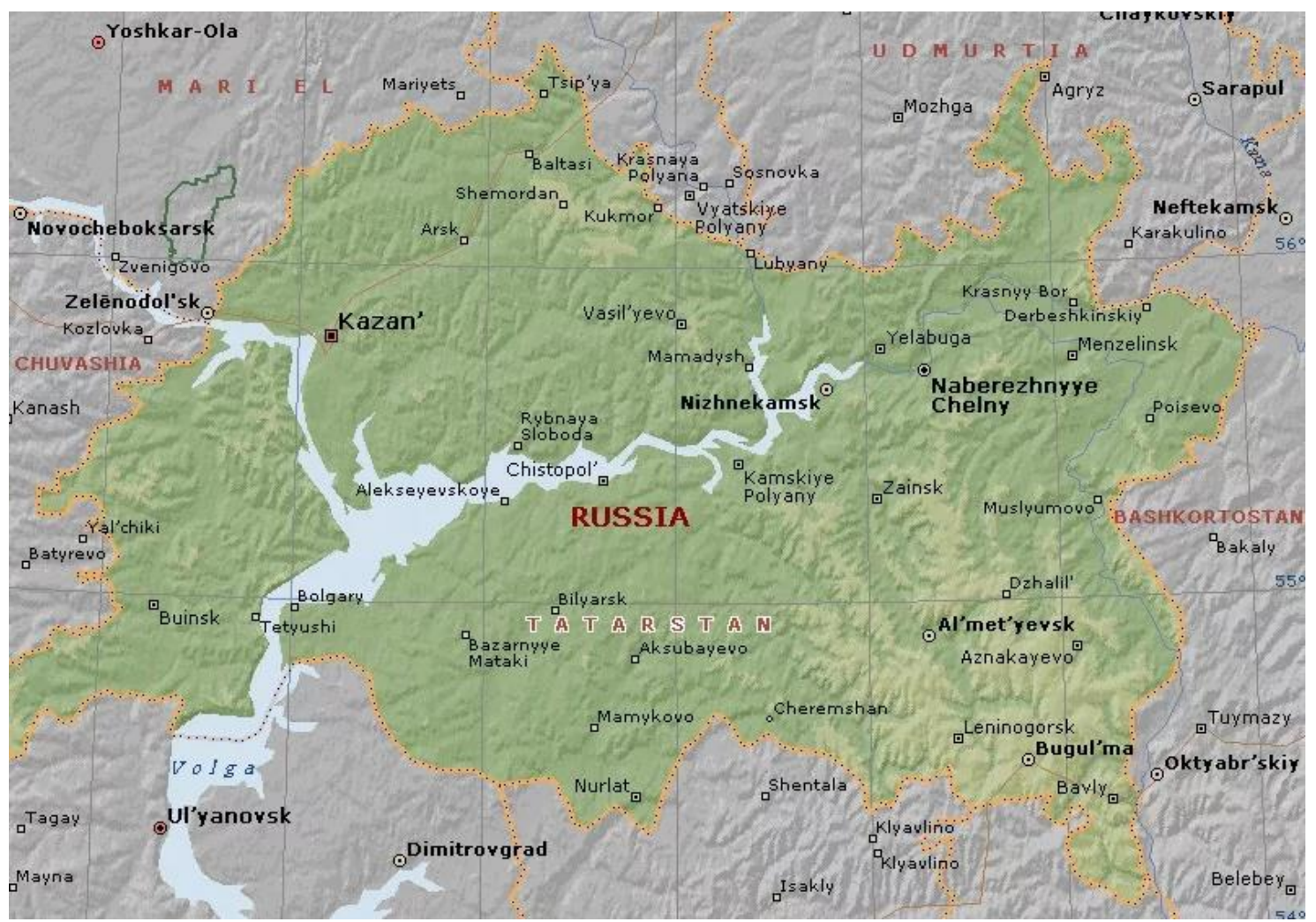

Figure 1. The map of the Republic of Tatarstan

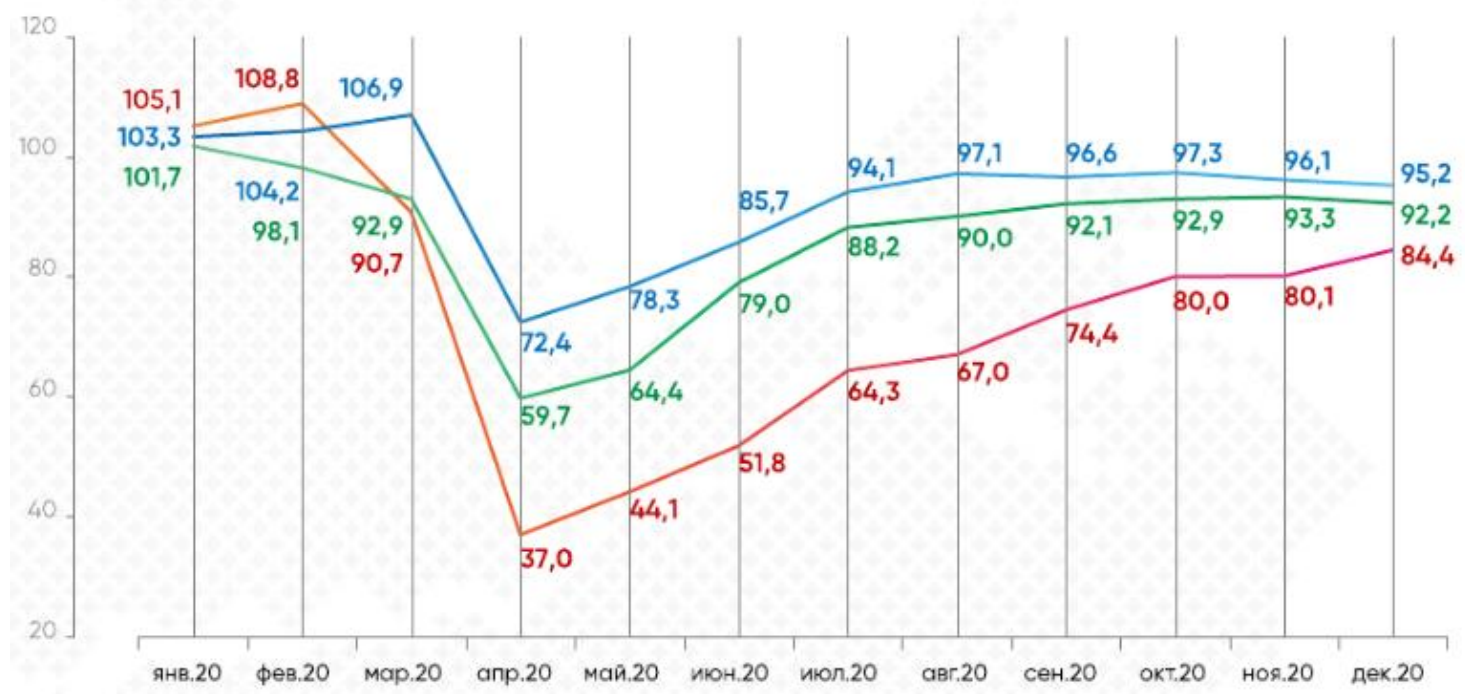

Figure 2. Trends in supply and demand in the territory of the Republic of Tatarstan in 2020 compared to 2019 


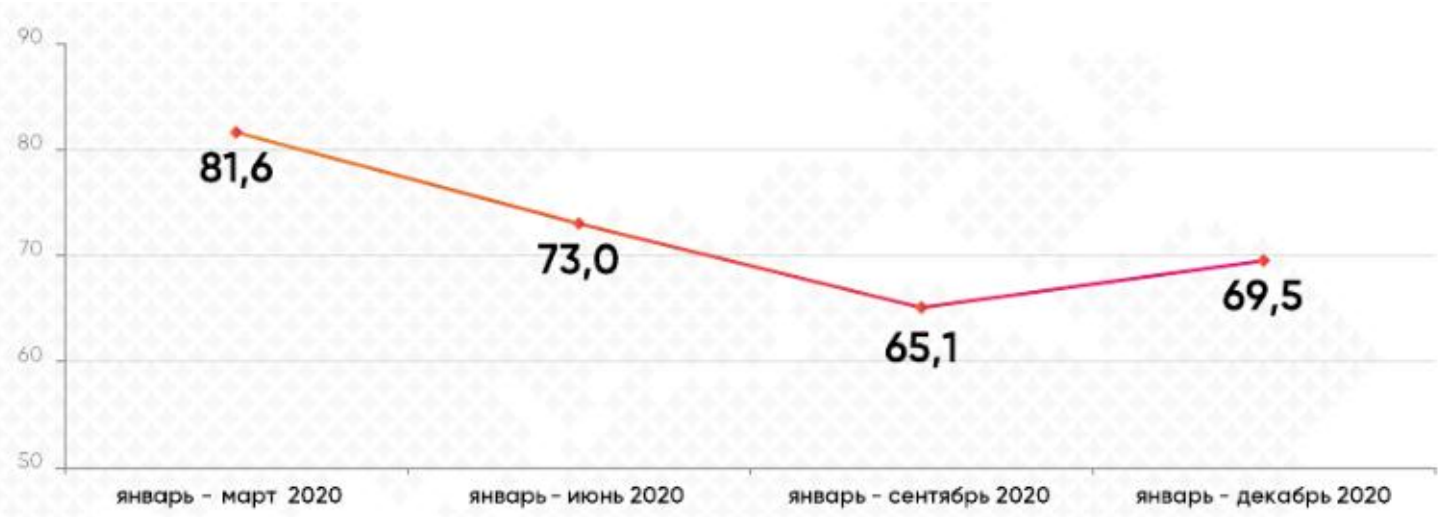

Figure 3. Violation of global cooperation and trade relations of the Republic of Tatarstan in 2020 compared to 2019

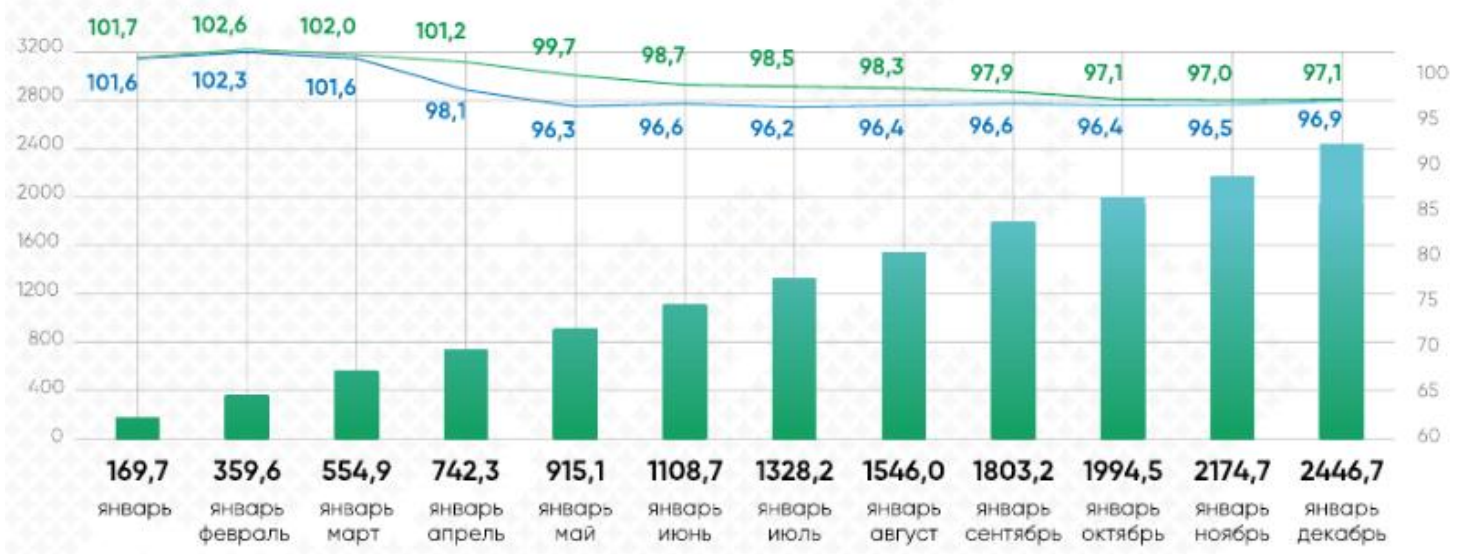

Figure 4. Dynamics of changes in the gross regional product (GRP) of the Republic of Tatarstan during 2020 compared to 2019 


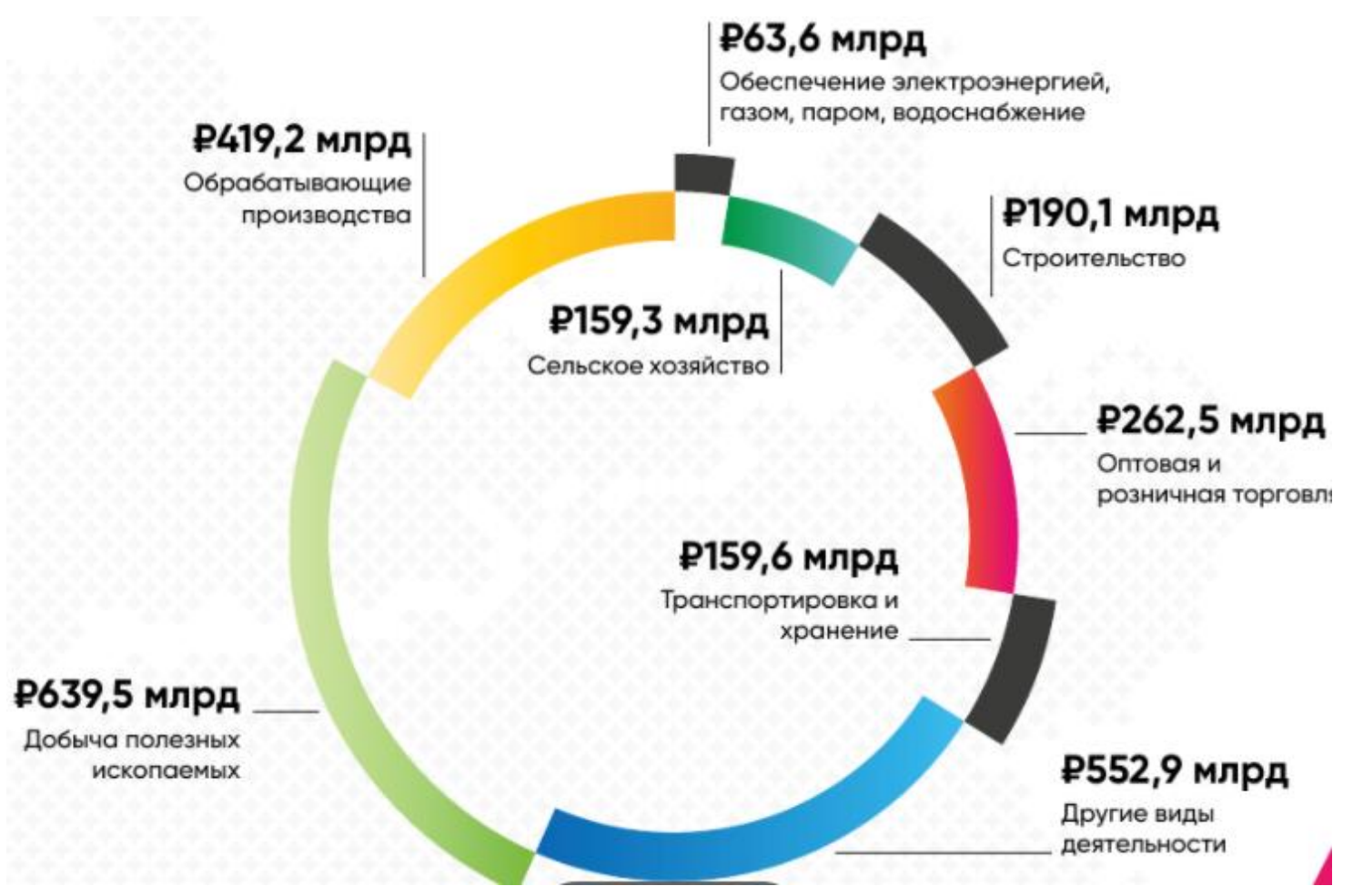

Figure 5. Structure of the GRP of the Republic of Tatarstan in 2020 in rubles

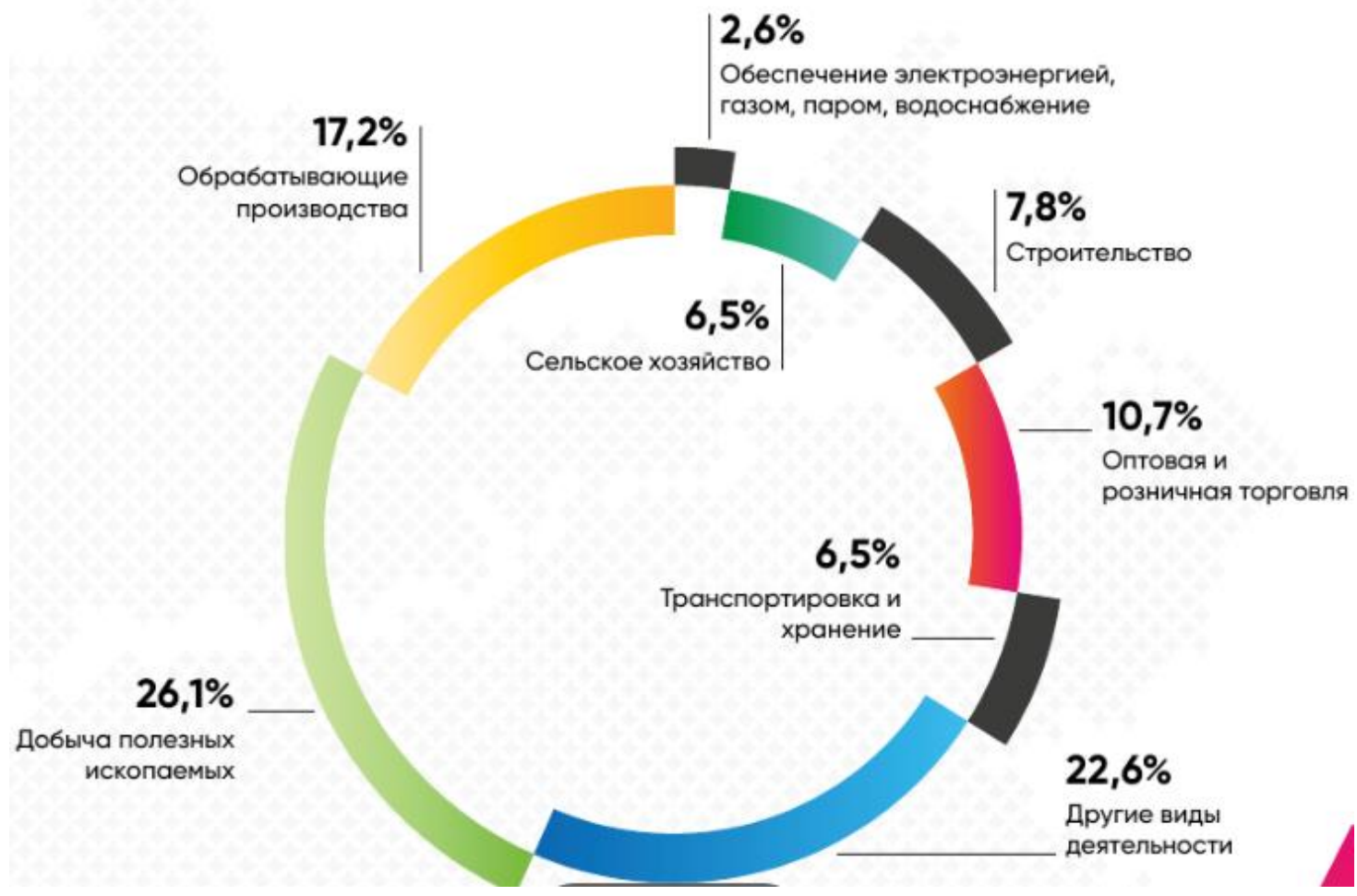

Figure 6. Structure of the GRP of the Republic of Tatarstan in 2020 in per cents. 